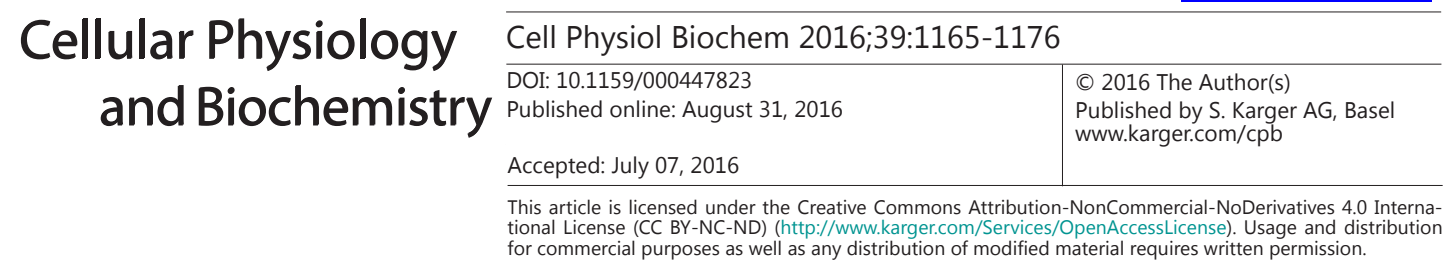

\title{
MiR-30a-5p Suppresses Tumor Metastasis of Human Colorectal Cancer by Targeting ITGB3
}

\author{
Wei Weia Yang Yang ${ }^{\mathrm{b}, \mathrm{c}}$ Jian Cai ${ }^{\mathrm{b}}$ Kai Cuid ${ }^{\mathrm{d}}$ Rong xian Lia Huan Wange \\ Xiujuan Shang ${ }^{a}$ Dong Wei ${ }^{b}$ \\ aDepartment of Anorectal, the Central Hospital of Xinxiang, Xinxiang, ${ }^{\text {bInstitute of Anal-Colorectal }}$ \\ Surgery, No.150 Central Hospital of PLA, Luoyang, 'Graduate School, the Second Military Medical \\ University, Shanghai, 'Department of Oncological Surgery, the Central Hospital of Xinxiang, Xinxiang, \\ eDepartment of Nephrology, the Central Hospital of Xinxiang, Xinxiang, China
}

\section{Key Words}

MiRNA-30a-5p • Colorectal cancer • Integrin $\beta 3 \cdot$ Metastasis

\begin{abstract}
Aims: MicroRNAs (miRNAs) are dysregulated in a wide range of malignant diseases, confirming their crucial role in tumor metastasis. MiRNA-30a-5p, a member of the miR-30 family, has been implicated in many types of cancers, including colorectal cancer, a leading cause of death worldwide. Methods: qRT-PCR, Western blot, Transwell assay,luciferase reporter assay were performed in the present study. Results: In this study, miR-30a-5p was found to be significantly downregulated in human colorectal cancer tissue specimens and cell lines compared with non-cancerous tissues and cells. The overexpression of miR-30a-5p inhibited the migratory and invasive abilities of colorectal cancer cells and suppressed the epithelial-mesenchymal transition, a crucial process in metastasis. Bioinformatic algorithms and luciferase reporter assays revealed that integrin $\beta 3$ (ITGB3) is a direct target of miR-30a$5 p$. Importantly, overexpression of ITGB3 in colorectal cancer cells rescued these cells from miR-30a-5p-mediated suppression of metastasis and restored the epithelial-mesenchymal transition. Conclusion: Taken together, our study provides the first evidence that miR-30a-5p suppresses colon cancer metastasis through the inhibition of ITGB3. Thus, targeting miR-30a$5 p$ might serve as a promising therapeutic strategy for the treatment of colorectal cancer.
\end{abstract}

(C) 2016 The Author(s)

Published by S. Karger AG, Basel

\section{Introduction}

MiRNAs are evolutionarily conserved, endogenous, non-coding small RNAs (18-25 nucleotides in length) that negatively regulate gene expression by binding to specific target mRNAs, leading to either cleavage or translational inhibition [1]. It is now believed that each W. Wei, Y. Yang and J. Cai contributed equally. 


\section{Cellular Physiology Cell Physiol Biochem 2016;39:1165-1176 \begin{tabular}{ll|l} 
and BiOChemistry & $\begin{array}{l}\text { DOI: 10.1159/000447823 } \\
\text { Published online: August 31, } 2016\end{array}$ & $\begin{array}{l}\text { C } 2016 \text { The Author(s). Published by S. Karger AG, Basel } \\
\text { www.karger.com/cpb }\end{array}$
\end{tabular} \\ Wei et al.: MiRNA-30a Suppresses CRC Metastasis via ITGB3}

miRNA is capable of modulating the expression of hundreds of target genes, thereby affecting a diverse range of biological processes [2]. Over the last decade, miRNAs have been recognized as critical regulators in the development and progression of cancer via the modulation of cellular pathways, such as those involved in proliferation [3], differentiation [4, 5], apoptosis $[6,7]$ and invasion [8-10]. In a number of human cancers, including colon, breast, lung and stomach cancer, as well as leukemia and lymphoma, miRNA expression profiles have been reported to differ significantly between carcinoma cells and corresponding non-carcinoma cells $[3,4,11]$. The dysregulation of miRNA expression in a wide range of malignant diseases has confirmed the crucial role of miRNAs in tumor metastasis [12], however, in many cases it remains to be determined which step(s) in the multistep metastatic process these miRNAs regulate.

In the case of colorectal cancer (CRC), one of the leading causes of death worldwide [13], global miRNA expression analyses have identified multiple dysregulated miRNAs including miRNA-21 [14], miRNA-124 [15], miRNA-625 [16], miRNA-339-5p [17], miRNA-27b [18], although their functional roles are yet to be confirmed experimentally in the majority of cases. It was confirmed that a series of miRNAs, including miR-140-5p [19], miR-149 [20], miR-301 $\alpha$ [21], play importat roles in the development of colorectal cancer. In addition, miRNA 30a(miR-30a-5p), a member of the miR-30 family, has been repeatedly reported to be downregulated in a number of cancers including CRC [22-24]. Studies have shown that miRNA-30a can act as a tumor suppressor, inducing growth inhibition and suppression of cell migration and invasion in CRC, by targeting denticleless protein homolog, PIK3CD and insulin receptor substrate 2 [25-27]. miRNAs have also been reported to modulate the expression of integrins, transmembrane receptors involved in signal transduction, and dysfunction in miRNA-regulated integrin signaling has been linked to tumor metastasis and apoptosis in a number of cancers including CRC [28].

The conversion of an epithelial cell to a mesenchymal cell, known as epithelialmesenchymal transition (EMT) is critical to embryonic morphogenesis. It is also now wellestablished that EMT plays a specific role in the migration of cells from a primary tumor into the circulation, the process of metastasis, which is often a crucial prognostic factor [29-31]. The loss of epithelial functions and the acquisition of mesenchymal functions during EMT is accompanied by increased migratory and invasive properties. TGF- $\beta$ and RTK/Ras signaling, autocrine factors and Wnt-, Notch-, Hedgehog- and NF-кB-dependent pathways have been reported to contribute to EMT. Repression of E-cadherin by transcriptional regulators such as Snai 1 or Twist is known to be a critical step driving EMT [32]. In fact, reduced E-cadherin protein expression (an epithelial-specific marker) is used as an indicator of EMT, as is increased expression of vimentin (a mesenchymal-specific marker) [33]. A recent report by Liu et al. [10] identified Snai1 as a direct target of miRNA-30a and demonstrated miRNA-30a as a novel regulator of EMT. Similarly, another study reported that miRNA-29b suppresses CRC metastasis by regulating EMT via its target Tiam1 [34].

Here, we investigated further the role of miRNA-30a-5p in CRC progression and the mechanisms underlying the function of miR-30a-5p in CRC metastasis. We identified ITGB3 as a direct target of miR-30a-5p and revealed the relationship between miR-30a-5p, ITGB3 and the EMT.

\section{Materials and Methods}

\section{Clinical specimens}

Fresh primary CRC specimens (with and without metastases) and noncancerous colorectal tissue were provided by the Tumor Tissue Bank of the Central Hospital of Xingxiang (Xinxiang, Henan, China). In each case, a diagnosis of primary CRC had been made, and the patient had undergone elective surgery for CRC in the Centrol Hospital of Xingxiang between 2007 and 2010. The pathological diagnosis was made in the Department of Pathology of the Centrol Hospital of Xingxiang. 


\section{Cellular Physiology Cell Physiol Biochem 2016;39:1165-1176 and Biochemistry Published online: August 31, $2016 \quad$\begin{tabular}{l|l} 
DOI: $10.1159 / 000447823$ & $\begin{array}{l}\text { (c) } \\
\text { www.karger.com/cpb }\end{array}$
\end{tabular} \\ Wei et al.: MiRNA-30a Suppresses CRC Metastasis via ITGB3}

\section{Cell lines and culture conditions}

Human colon cancer cell lines (HT29, LoVo, SW116 and SW480), and HEK293T cells, were cultured in RPMI1640 medium (Thermo Scientific HyClone, Beijing, China) supplemented with $10 \%$ fetal bovine serum, and the normal human colon epithelial cell line NCM460 was cultured in M3 base culture media (Incell Corporation, San Antonio, TX, USA) as previously described [35]. Both media contained 10\% fetal bovine serum, $100 \mathrm{U} /$ $\mathrm{ml}$ penicillin $\mathrm{G}$ and $100 \mu \mathrm{g} / \mathrm{ml}$ streptomycin (Gibco Laboratories). All cells were cultured at $37^{\circ} \mathrm{C}$ in a humidified incubator containing $5 \% \mathrm{CO}_{2}$.

\section{Lentiviral production and infection oligonucleotide transfection}

The miR-30a-5p precursor sequence was amplified with the following primers: $5^{\prime}$-TAC GGA TCC CCT TCA TCT TAC TTT TTT CCC CCA A-3' (forward) and 5'-ATC GCT AGC GAA ACT AGAAGCTCGGTGATGAATA-3' (reverse). These sequences were cloned into the lentivirusbased expression plasmid pLenti6.3 (Invitrogen). Virus packaging and infection were performed according to standard protocols as recommended by the manufacturer. Lovo and SW480 cells $\left(1 \times 10^{5}\right)$ were infected with $1 \times 10^{7}$ lentivirus transducing units in the presence of $10 \mu \mathrm{g} / \mathrm{ml}$ polybrene (Sigma, St Louis, Missouri, USA). Empty lentiviral vector was used as negative control. Cells were collected $48 \mathrm{~h}$ after transfection.

\section{qRT-PCR analysis}

Total RNA was extracted with Trizol reagents (Life Technologies, CA, USA) according to the manufacturer's instructions. Then, $1 \mu \mathrm{g}$ of RNA was reverse transcribed into cDNA using a reverse reaction kit (Promega, Madison, WI, USA). qRT-PCR was then performed using specific primers and the 7500 real-time PCR system (Applied Biosystems, Mannheim, Germany). U6 was used as the endogenous control for miRNA expression analysis. Relative quantification analysis was performed using the comparative threshold cycle (CT) method $(2-\Delta \Delta \mathrm{CT})[36]$.

\section{Transwell assay}

Migration and invasion of LoVo and SW480 cells were assessed using Transwell plates (Millipore). Cells were plated on uncoated upper chambers (24-well inserts; pore size, 8 mm; BD Bioscience, Bedford, MA, USA) for Transwell migration assays. Cells were plated on Matrigel-coated upper chambers (24-well inserts; pore size, $8 \mathrm{~mm}$; BD Bioscience) for invasion assays. Briefly, fresh media containing $5 \%$ fetal bovine serum (FBS) were placed in the lower wells. Cells were incubated for $24 \mathrm{~h}$ in medium containing $1 \% \mathrm{FBS}$, trypsinized, and suspended at a final concentration of $1 \times 10^{6}$ cells $/ \mathrm{mL}$ in medium containing $1 \%$ FBS. Then, $200 \mathrm{~mL}$ of the cell suspension was loaded into each of the upper wells, and the chamber was incubated at $37^{\circ} \mathrm{C}$ for $24 \mathrm{~h}$. Non-migrating cells on the upper surface of the filter were removed by wiping with a cotton swab. Chemotaxis was quantified by counting the cells that migrated to the lower side of the filter for eight random fields in each assay with an optical inverted microscope $(\times 200$, Nikon, Tokyo, Japan).

Western blot analysis

Equal amounts of cell lysate were separated by 10\% SDS-PAGE, and electrophoretically transferred to PVDF membrane. The membrane was blocked and probed with mouse antihumanITGB3 monoclonal antibody (Abcam, Cambridge, UK), followed by horseradish peroxidase-labeled goat-anti-mouse IgG (Abcam). Chemiluminescence was used to analyze protein levels and $\beta$-actin was used as a protein loading control.

\section{Bioinformatic analysis}

Potential miRNA targets were predicted and analyzed using three publicly available algorithms: PicTar, TargetScan and miRanda [37]. The number of false-positive results was decreased by accepting only putative target genes that were predicted by at least two programs. 


\section{Cellular Physiology Cell Physiol Biochem 2016;39:1165-1176

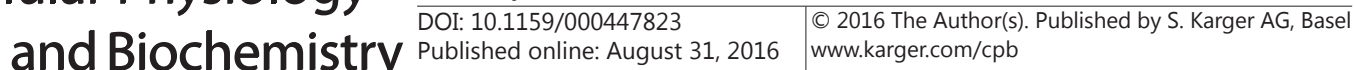 \\ Wei et al.: MiRNA-30a Suppresses CRC Metastasis via ITGB3}

\section{Luciferase reporter assay}

HEK293T cells were seeded in a 96-well plate at 50-60\% confluence. After $24 \mathrm{~h}$, cells were transfected with 120 ng of miRNA-30a-5p expression vector, miRNA-30a-5p inhibitor, control vector, or negative control. Cells were co-transfected with $30 \mathrm{ng}$ of the wild-type or mutant 3'-UTR of ITGB3 mRNA. Transfections were performed using $0.45 \mu \mathrm{L}$ of Fugene (Promega, Madison, WI, USA). Cells were collected $48 \mathrm{~h}$ after transfection, and Renilla luciferase activity was measured using a dual-luciferase reporter system (Promega). Luciferase reporter assays were performed in duplicate and repeated in three independent experiments. Luciferase activity was detected using an Orion II microplate luminometer (Berthold Technologies, Germany).

\section{Liver metastasis model}

Mice were injected with SW480 colon cancer cells in the spleen to produce liver metastasis. The mice were anesthetized with $2.5 \%$ pentobarbital sodium by peritoneal injection. After sterilization of the skin in the area of surgery, an abdominal incision paralleling the left subcostal margin was made. Tumor cells $\left(1 \times 10^{7}\right)$ in $100 \mu$ phosphatebuffered saline solution were injected into the spleen. Mice were euthanized 5 weeks after tumor cell implantation. Liver metastases were examined and counted under a dissecting microscope equipped with bright field imaging.

\section{Statistical analysis}

Statistical analysis was performed using SPSS 15.0 software (SPSS Inc., Chicago, IL, USA). Data are expressed as the mean \pm SEM. The difference between two independent groups was assessed using a two-tail Student's t test. A p value $<0.05$ was considered statistically significant. All experiments were performed in triplicate.

\section{Results}

MiR-30a-5p is downregulated in CRC tissue and cell lines

We compared miR-30a-5p expression in 40 CRC tissues with metastases (mCRC) and 27 CRC tissues without metastases (nmCRC) and 40 normal non-cancerous matched tissues (Normal) by qRT-PCR. The average relative expression level of miR-30a-5p was significantly lower in CRC specimens compared with non-cancerous tissues (Fig. $1 \mathrm{~A}, \mathrm{P}<0.01$ ). Decreased expression of miR-30a-5p was also observed in all four CRC cell lines tested (HT29, LoVo, SW116 and SW480) compared with the normal human colon epithelial cell line NCM460 or
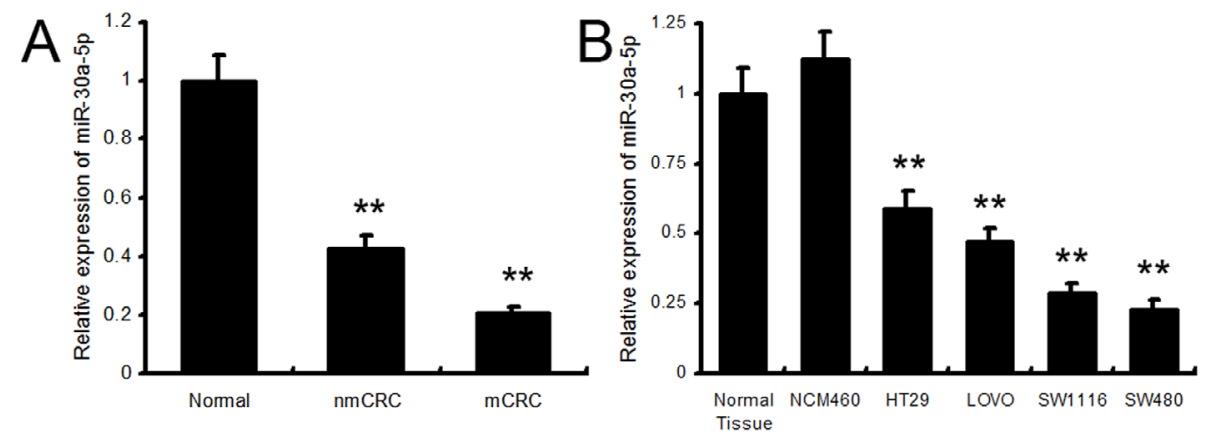

Fig. 1. Downregulated expression of miR-30a-5p in CRC tissues and cell lines. (A) miR-30a-5p expression in CRC tissues with or without metastases relative to normal matched tissues, as determined by qRT-PCR. nmCRC denotes CRC tissues without metastases; mCRC denotes CRC tissues with metastases. (B) The relative expression of miR-30a-5p in four CRC cell lines (HT29, LoVo, SW1116, SW480) compared with the normal human colon epithelial cell line NCM460 or the mean rate of expression of miR-30a-5p in 24 non-cancerous tissue samples (Normal tissue), as determined by qRT-PCR. ${ }^{* *} \mathrm{P}<0.01$. 

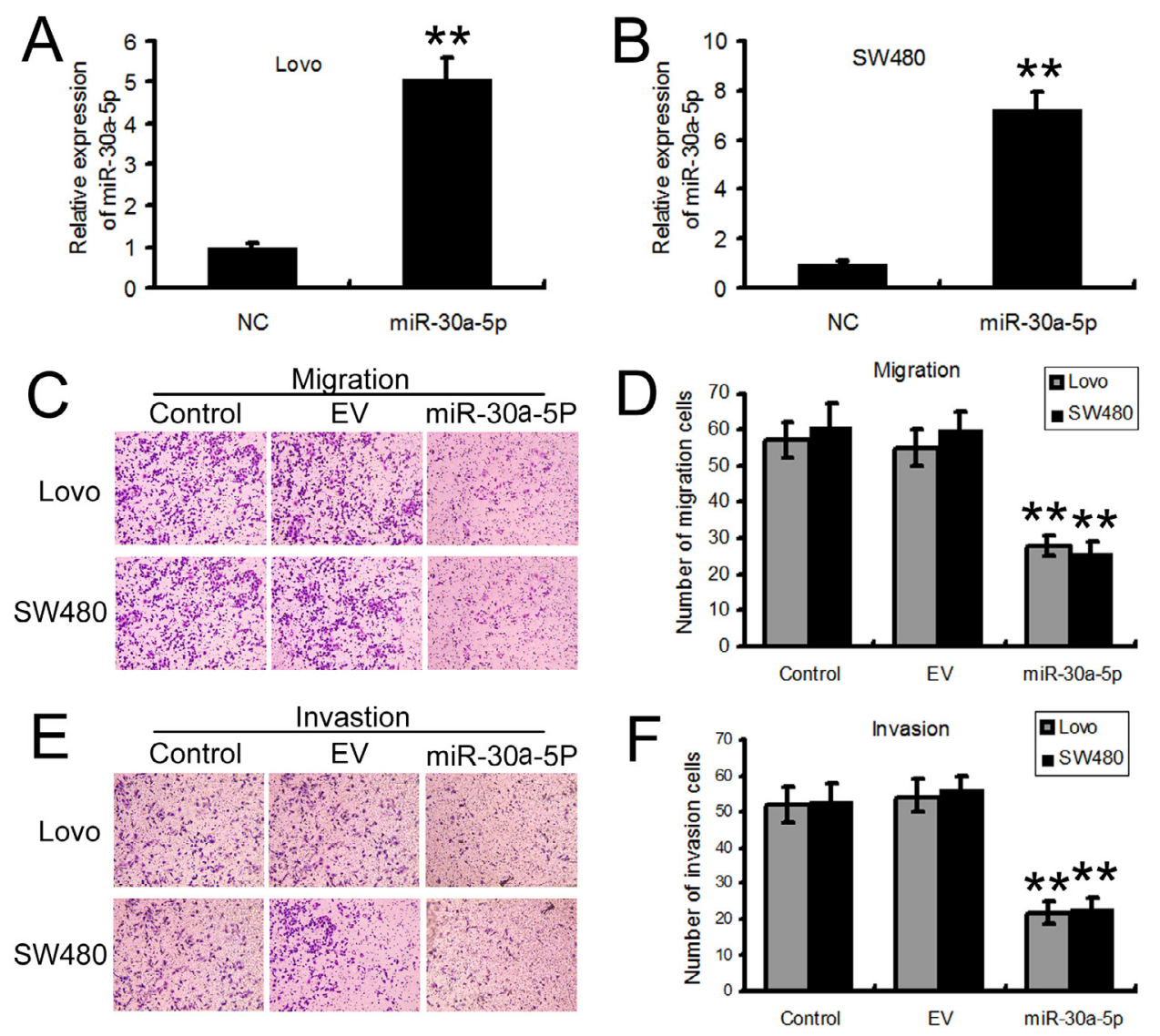

Fig. 2. Ectopic expression of miR-30a-5p inhibited aggressive phenotypes in CRC cells. Relative expression levels of miR-30a-5p in LoVo (A) and SW480 (B) CRC cells transfected with miR-30a-5p compared with normal control (NC) cells, as determined by qRT-PCR. The number of migratory (C) and invasive (D) cells, as determined by Transwell assays at $48 \mathrm{~h}$ post-transfection, for Lovo or SW480 CRC cells transfected with miR-30a-5p compared with empty lentivector treatd (EV) or normal control (NC) cells, magnification $\times 200$. Quantification of the migratory (E) and invasive (F) cell numbers determined by the Transwell assay. $* * \mathrm{P}<0.01$.

the normal non-cancerous tissue specimens (Fig. $1 \mathrm{~B}, \mathrm{P}<0.01$ ). These findings indicated that miR-30a-5p is downregulated in CRC tissue and CRC cell lines.

\section{Exogenous miR-30a-5p suppresses CRC cell metastasis}

We transfected the CRC cell lines LoVo and SW480 (which have a lower level of endogenous expression of miR-30a-5p) with a miR-30a-5p mimic and confirmed miR$30 \mathrm{a}-5 \mathrm{p}$ overexpression by qRT-PCR (Fig. $2 \mathrm{~A}$ and $\mathrm{B}, \mathrm{P}<0.01$ ). At $48 \mathrm{~h}$ post-transfection, the effects of miR-30a-5p on cell migration and invasion were assessed by Transwell assays. We found that the number of migratory (Fig. 2C and E) and invading (Fig. 2D and F) cells were decreased for both miR-30a-5p-transfected CRC cell lines compared with control cells and EV (empty lentivector treatd)cells $(\mathrm{P}<0.01$ for both). These findings indicate that ectopic expression of miR-30a-5p inhibited aggressive phenotypes in CRC cells.

\section{Exogenous miR-30a-5p effects EMT in CRC cells}

To investigate the effect of exogenous miR-30a-5p on EMT, western blot analysis was performed on the LoVo and SW480 CRC cell lines transfected with miR-30a-5p compared with the EV and control cells. We found that exogenous miR-30a-5p upregulated E-cadherin expression in both CRC cell lines $(\mathrm{P}<0.01$; Fig. $3 \mathrm{~A}$ and $\mathrm{B})$ and downregulated vimentin 
Fig. 3. Effect of ectopic expression of miR-30a-5p on expression of the epithelial-mesenchymal transition

(EMT) markers Expression of the EMT markers, E-cadherin and vimentin, was analyzed by western lotting in the (A) LoVo and (B) SW480 CRC cell lines transfected with miR30a-5p compared with EV or normal control (NC) cells. $\beta$-actin was included as a loading control. ${ }^{* *} \mathrm{P}<0.01$.
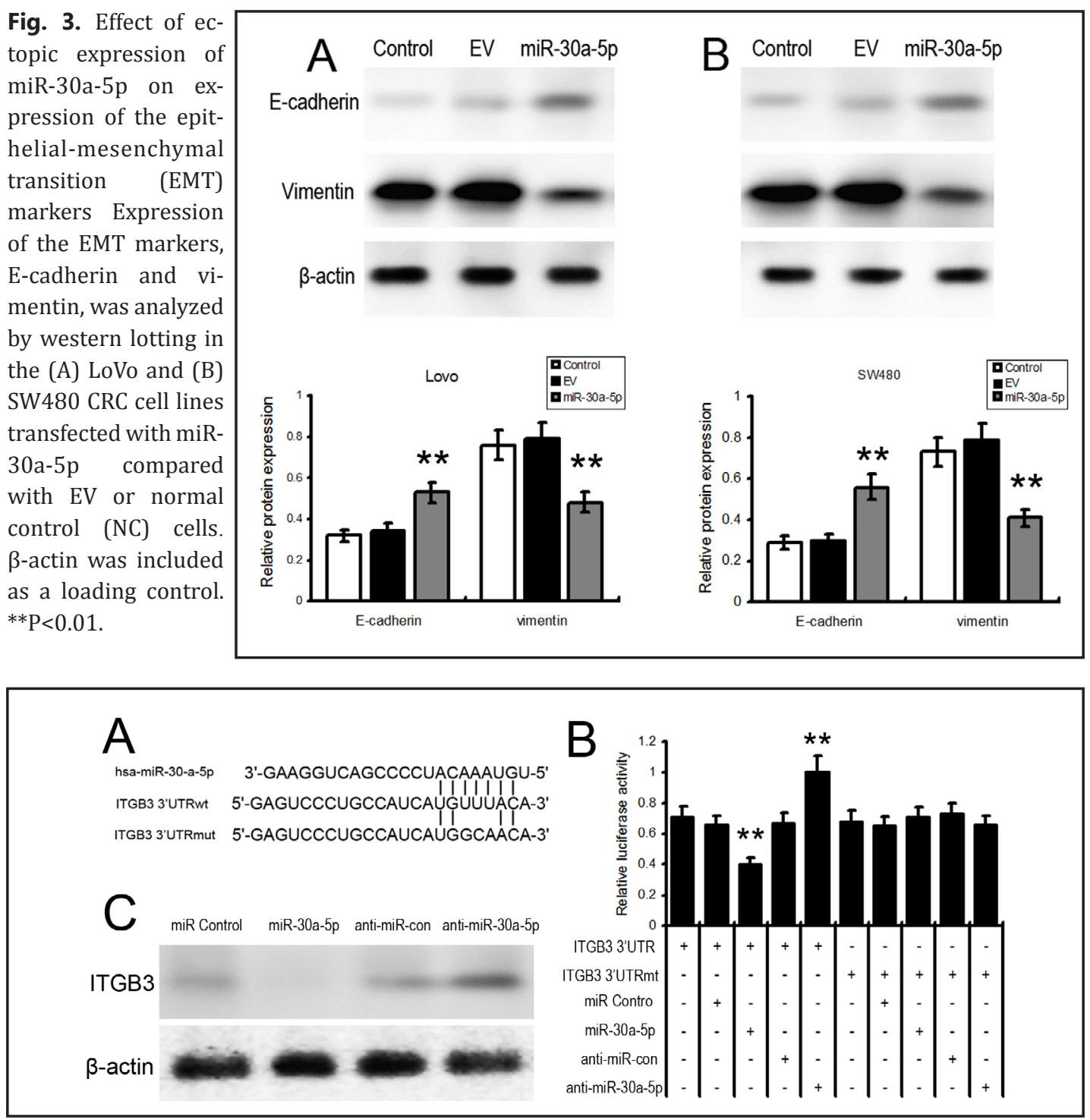

Fig. 4. ITGB3 is a target of miR-30a-5p. (A) The sequence of miR-30a-5p and the 3 'UTR of ITGB3 used in the reporter assay. The wild-type and mutant sequences of the ITGB3 3'UTR are shown. The putative binding site between miR-30a-5p and the ITGB3 3'UTR is indicated. (B) The relative luciferase activities observed in reporter assays of HEK-293T cells transfected with reporter vectors containing either the wild-type or mutated 3'UTR of ITGB3, and a miR-30a-5p mimic, anti-miR-30a-5p or their nonspecific controls. (C) Protein levels of ITGB3 in SW480 cells transfected with miR-30a-5p mimic, anti-miR-30a-5p or their nonspecific controls. ${ }^{* *} \mathrm{P}<0.01$.

expression ( $\mathrm{P}<0.01$; Fig. 3A and B). E-cadherin and vimentin are markers of EMT. Reduced expression of the epithelial-specific marker E-cadherin, accompanied by increased expression of the mesenchymal-specific marker vimentin, is indicative of EMT (Zeisberg and Neilson, 2009). Our findings therefore indicate that exogenous miR-30a-5p inhibits EMT in CRC cells, which is consistent with the suppression of invasive and migratory properties in these cells shown in Fig. 2.

\section{ITGB3 is a target for repression by miR-30a-5p}

MiRNAs act by binding to the 3'UTR of target genes sharing sequence homology within the seed sequence. To explore miR-30a-5p-regulated target gene(s) and pathway(s), we used three publicly-available miRNA target prediction tools: Targetscan, ncRNA and mirecords. 


\section{Cellular Physiology Cell Physiol Biochem 2016;39:1165-1176 \begin{tabular}{l|l|l} 
and Biochemistry Published online: August 31, 2016 & $\begin{array}{l}\text { (c) } 2016 \text { The Author(s). Published by S. Karger AG, Basel } \\
\text { www.karger.com/cpb }\end{array}$
\end{tabular} \\ Wei et al.: MiRNA-30a Suppresses CRC Metastasis via ITGB3}

Fig. 5. ITGB3 rescues the suppressive effect of miR-30a-5p on CRC cell metastasis. (A) ITGB3 expression was determined by western blot analysis in cells transfected with miR-30a-5p mimics alone or in combination with either pcDNA $3.1+$ (vector) or pcDNA 3.1+ containing a wild-type (ITGB3) or mutant ITGB3 (ITGB3 mut) expression cassette of the miR-30a-5p response element. $\beta$-actin was included as an internal control. $(B, C)$ Invasion and migration of the same set of CRC cells were assessed using Transwell assays. (D) Quantification of invasive and migratory CRC cells. ${ }^{* *} \mathrm{P}<0.01$ vs. control.

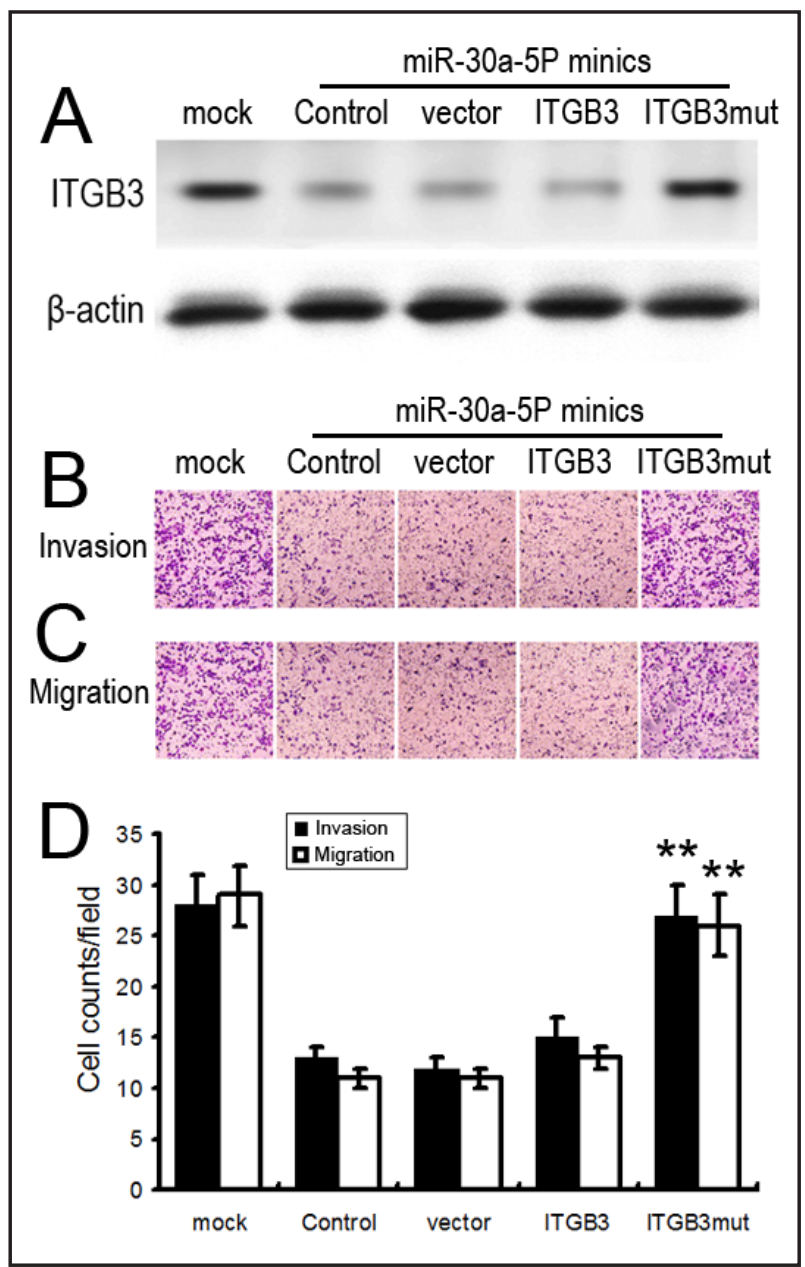

To increase the stringency of the target prediction protocol, we searched for mRNAs simultaneously predicted by all three target-prediction programs and selected ITGB3 as a potential target. To assess whether miR-30a-5p could directly alter the expression of ITGB3, a putative binding site for miR-30a-5p in the 3'UTR of ITGB3 was identified (Fig. 4A) and this mRNA fragment (wt 3'UTR), along with a mutated derivative of this sequence (mut 3'UTR), were cloned into a luciferase reporter vector. HEK-293T cells were then transfected with the reporter vectors containing either the wt or mut 3'UTR of ITGB3 and a miR-30a-5p mimic. As shown in Fig. 4B, luciferase expression was decreased when the wt 3'UTR and miR-30a-5p mimic were cotransfected $(\mathrm{P}<0.01)$, while cotransfection with the mut 3 'UTR had no effect on luciferase activity. Moreover, cotransfection of HEK-293T cells with the wt 3'UTR and anti-miR-30a-5p reversed the effect seen with the miR-30a-5p mimic $(\mathrm{P}<0.01)$.

Collectively, these results indicated that ITGB3 is a direct target of miR-30a-5p. We next elucidated whether the growth-suppressive effect of miR-30a-5p was mediated by repression of ITGB3. We assessed whether expression of ITGB3 changed in response to transfection with the miR-30a-5p mimic or anti-miR-30a-5p in SW480 cells by western blot analysis. Compared with the nonspecific controls, expression of ITGB3 was significantly decreased by miR-30a-5p transfection and increased by anti-miR-30a-5p transfection (Fig. 4C), indicating that miR-30a-5p decreases ITGB3 expression.

ITGB3 rescues the suppressive effect of miR-30a-5p on CRC cell metastasis

To identify whether miR-30a-5p inhibits the invasiveness of CRC cells by targeting ITGB3, we performed a "rescue" experiment by co-transfecting SW480 CRC cells with miR-30a-5p mimics and a pcDNA3.1 vector that expresses ITGB3 with a mutated miR-30a seed sequence 


\section{Cellular Physiology Cell Physiol Biochem 2016;39:1165-1176 \begin{tabular}{ll|l} 
DOI: 10.1159/000447823 & $\begin{array}{l}\text { O 2016 The Author(s). Published by S. Karger AG, Basel } \\
\text { www.karger.com/cpb }\end{array}$
\end{tabular}

Fig. 6. ITGB3 restores the expression of vimentin and inhibits the expression of E-cadherin. ITGB3, vimentin and E-cadherin expression were determined by western blot analysis in cells transfected with miR-30a-5p mimics alone or in combination with either pcDNA 3.1+ (vector) or pcDNA 3.1+ containing a wild-type (ITGB3) or mutant ITGB3 (ITGB3 mut) expression cassette of the miR-30a-5p response element. $\beta$-actin was included as an internal control.

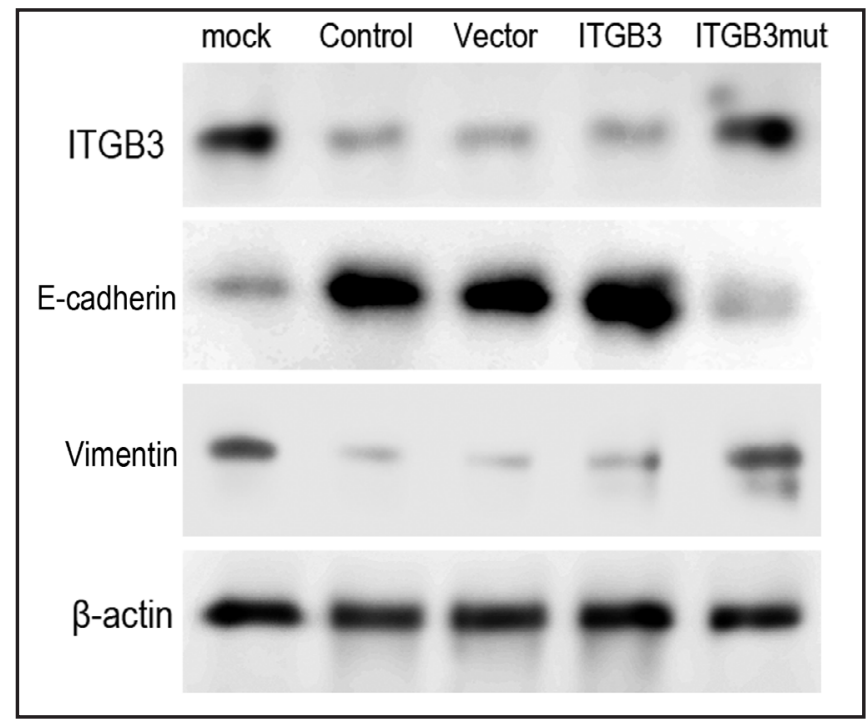

Fig. 7. Effect of Overexpression of miR30a-5P or knockdown of ITGB3 on colon cancer cell metastasis in a mice model. SW480 cells and SW480 transfected with miR-30a-5P mimics or ITGB3-siRNA were injected into spleen of mice. After 5 weeks, the livers were resected and the number of metastatic lesions were measured.

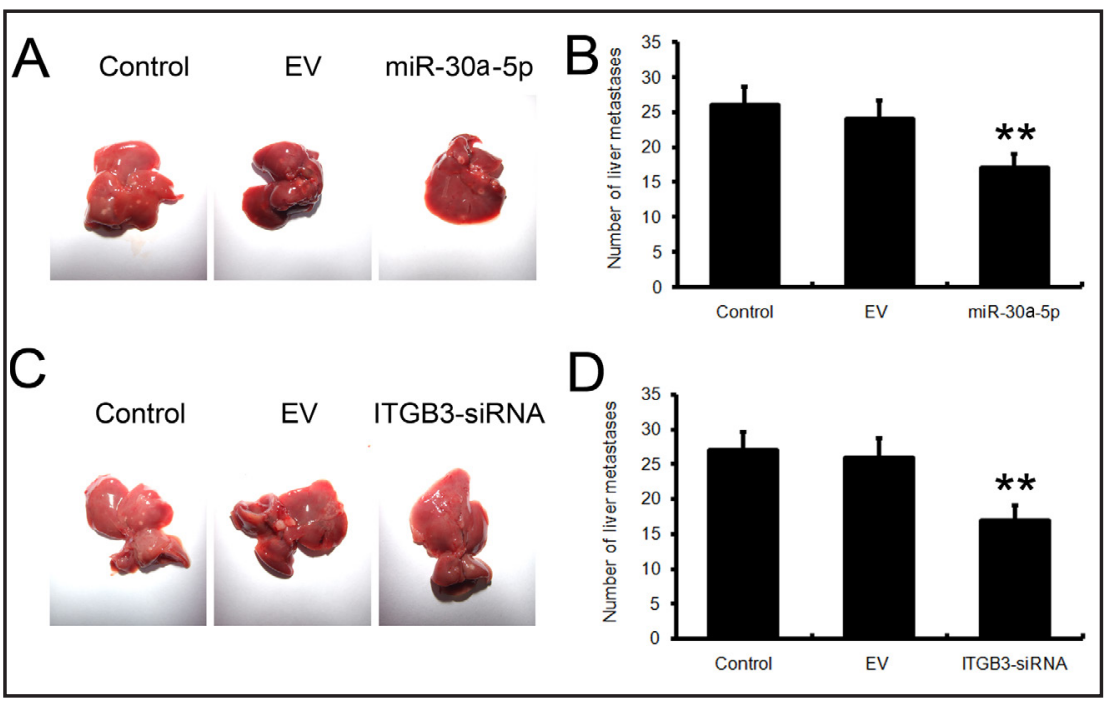
(A\&C) Representative images of liver tumors are shown. (B\&D) Quantitative evaluation of visible liver metastases on the surface of whole livers. Data represent the mean $\pm \mathrm{SD}$. ${ }^{*} \mathrm{P}<0.01, \mathrm{n}=5$.

(ITGB3 mut) in the 3'-UTR. Western blot analysis demonstrated that co-transfection of CRC cells with miR-30a-5p mimics and ITGB3 mut restored ITGB3 expression, whereas cotransfecting wild-type pcDNA3.1-ITGB3 could not restore ITGB3 expression after silencing by miR-30a-5p mimics (Fig. 5A).

Next, invasion and migration of CRC cells were assessed using Transwell assays. "Rescuing" ITGB3 expression in the presence of miRNA mimics restored the invasive and migratory capacities of SW480 cells $(\mathrm{P}<0.01$; Fig. 5, B-D). Collectively, these data suggested that miR-30a-5p regulates the invasiveness of CRC cells by targeting ITGB3.

ITGB3 rescues the suppressive effect of miR-30a-5p on EMT

Finally, we investigated the effect of ITGB3 on EMT. Western blot analysis of ITGB3, vimentin and E-cadherin expression in cells co-transfected with miR-30a-5p mimics and pcDNA3.1-ITGB3 harboring the wild-type or mutant miR-30a-5p response element, revealed that ITGB3 restored the expression of vimentin and inhibited the expression of E-cadherin (Fig. 6), thereby rescuing the suppressive effect of miR-30a-5p on EMT.

\section{KARGER}




\section{Cellular Physiology Cell Physiol Biochem 2016;39:1165-1176 and Biochemistry Published online: August 31, $2016 \quad$\begin{tabular}{l|l} 
DOI: $10.1159 / 000447823$ & $\begin{array}{l}\text { (c) } \\
\text { www.karger.com/cpb }\end{array}$
\end{tabular} \\ Wei et al.: MiRNA-30a Suppresses CRC Metastasis via ITGB3}

Overexpression of miR-30a-5P or knockdown of ITGB3 inhibits hepatic metastasis of colon cancer cell in vivo

SW480 cells $\left(1 \times 10^{7}\right)$ were injected into the spleen of 30 mice to establish liver metastasis [38] and sacrificed 5 weeks after tumor cell injection for analysis. At 5 weeks after injection, the number of metastases in the livers of mice injected with SW480 cells transfected with miR-30a-5p was significantly lower than that of control and EV SW480 injected mice (Fig. $7 A \& B)$. Similar to this, the number of metastases in the livers of mice injected with ITGB3siRNA SW480 cells was significantly lower than that of control and EV SW480 injected mice (Fig. 7C\&D). These results indicated that miR-30a-5p suppresses metastasis of colon cancer cell and ITGB3 has the opposite effect.

\section{Discussion}

Although altered miRNA expression profiles have been observed in many types of malignancies $[39,40]$, the molecular mechanisms by which miRNAs modulate cancer cells largely remain to be determined. Here, we investigated the potential role of miRNA-30a$5 p$ in CRC progression. We demonstrated that miR-30a-5p was significantly downregulated in both human colon cancer tissues and cell lines, and found that downregulation of miR$30 a-5 p$ contributed to cancer cell migration and invasion, which was associated with EMT. Furthermore, we showed that ectopic expression of miR-30a-5p in CRC cells inhibited cell migration and invasion, preventing EMT. We investigated the mechanisms underlying the function of miR-30a-5p in colon cancer and using target prediction software and a dualluciferase reporter assay, identified ITGB3 as a direct target of miR-30a-5p. We then showed the involvement of ITGB3 in the functional consequences of miR-30a-5p suppression. Our findings indicate the important role of miR-30a-5p in the fundamental processes of CRC metastasis (i.e. migration, invasion and EMT). Local invasion and distant metastasis are strongly correlated with poor prognosis in CRC patients and determining the mechanisms that govern metastasis is therefore crucial in developing treatments to improve patient survival rates. Both miR-30a-5p and its physiological target, ITGB3, may therefore be promising candidates for the development of novel therapeutic strategies for CRC.

The aberrant expression and distribution of integrin family members, including ITGB3, has previously been shown to promote tumor metastasis [41-43]. Integrins are transmembrane receptors that mediate cell-to-cell and cell-extracellular matrix attachments and facilitate signal transduction via intracellular signaling pathways such as PI3K and MAPK. Integrin heterodimers (comprising $\alpha$ and $\beta$ subunits) regulate cell proliferation, survival and migration, predominantly via focal adhesion kinase and Src kinase family members [44, 45], with small GTPases acting as intermediates in this process. In one study, an ITGB3 antagonist led to decreased colon cancer metastasis in mice [46]. The binding of integrins to ligands on the extracellular matrix has been shown to transmit both mechanical and chemical signals to induce cell cytoskeleton remodeling during adhesion and migration. In another study, reactive oxygen species were shown to markedly upregulate the expression of ITGB3, promoting a more aggressive phenotype in a colorectal cancer cell line with increased migratory and invasive capacities [47]. MiRNAs have been linked with the dysregulation of integrin signaling in a number of studies, correlating miRNA-regulated integrin signaling with tumor metastasis and apoptosis in CRC [28], as well as breast, hepatocellular and salivary adenoid cystic carcinoma [7, 48, 49]. Our findings provide further evidence of the targeting of integrins by miRNAs.

In summary, we investigated the potential role of miR-30a-5p in tumor progression and its underlying mechanisms. Our findings indicate that downregulation of miR-30a-5p plays an important role in the development of CRC and that this miRNA is a promising therapeutic target. However, many aspects of miR-30a-5p function remain to be elucidated, including the complex effects on cellular behavior mediated by known targets (denticleless protein homolog, PIK3CD, insulin receptor substrate 2 and ITGB3) and potentially other yet to be determined target proteins. 


\section{Cellular Physiology Cell Physiol Biochem 2016;39:1165-1176 and Biochemistry \begin{tabular}{l|l} 
DOI: 10.1159/000447823 & (c) 2016 The Author(s). Published by S. Karger AG, Basel \\
www.karger.com/cpb
\end{tabular} \\ Wei et al.: MiRNA-30a Suppresses CRC Metastasis via ITGB3}

\section{Ethical approval}

This study was approved by the Ethics Committee of the Central Hospital of Xingxiang (Xinxiang, China) and all aspects of the study comply with the Declaration of Helsinki.

\section{Disclosure Statement}

The authors have no conflicts of interest.

\section{References}

1 Bartel DP: MicroRNAs: genomics, biogenesis, mechanism, and function. Cell 2004;116:281-297.

2 Friedman RC, Farh KK, Burge CB, Bartel DP: Most mammalian mRNAs are conserved targets of microRNAs. Genome Res 2009;19:92-105.

3 Hayashita Y, Osada H, Tatematsu Y, Yamada H, Yanagisawa K, Tomida S, Yatabe Y, Kawahara K, Sekido Y, Takahashi T: A polycistronic microRNA cluster, miR-17-92, is overexpressed in human lung cancers and enhances cell proliferation. Cancer Res 2005;65:9628-9632.

4 Chen CZ, Li L, Lodish HF, Bartel DP: MicroRNAs modulate hematopoietic lineage differentiation. Science 2004;303:83-86.

5 Yu F, Yao H, Zhu P, Zhang X, Pan Q, Gong C, Huang Y, Hu X, Su F, Lieberman J, Song E: let-7 regulates self renewal and tumorigenicity of breast cancer cells. Cell 2007;131:1109-1123.

6 Li J, Huang H, Sun L, Yang M, Pan C, Chen W, Wu D, Lin Z, Zeng C, Yao Y, Zhang P, Song E: MiR-21 indicates poor prognosis in tongue squamous cell carcinomas as an apoptosis inhibitor. Clin Cancer Res 2009;15:3998-4008.

7 Yu F, Deng H, Yao H, Liu Q Su F, Song E: Mir-30 reduction maintains self-renewal and inhibits apoptosis in breast tumor-initiating cells. Oncogene 2010;29:4194-4204.

8 Wellner U, Schubert J, Burk UC, Schmalhofer O, Zhu F, Sonntag A, Waldvogel B, Vannier C, Darling D, zur Hausen A, Brunton VG, Morton J, Sansom O, Schuler J, Stemmler MP, Herzberger C, Hopt U, Keck T, Brabletz S, Brabletz T: The EMT-activator ZEB1 promotes tumorigenicity by repressing stemness-inhibiting microRNAs. Nat Cell Biol 2009;11:1487-1495.

9 Paterson EL, Kazenwadel J, Bert AG, Khew-Goodall Y, Ruszkiewicz A, Goodall GJ: Down-Regulation of the miRNA-200 Family at the Invasive Front of Colorectal Cancers with Degraded Basement Membrane Indicates EMT Is Involved in Cancer Progression 1 2. Neoplasia 2013;15:180-191.

10 Liu MX, Zhou KC, Cao Y: MCRS1 overexpression, which is specifically inhibited by miR-129*, promotes the epithelial-mesenchymal transition and metastasis in non-small cell lung cancer. Mol Cancer 2014;13:245.

11 Couzin J: Cancer biology. A new cancer player takes the stage. Science 2005;310:766-767.

12 Andrea V, Tyler J: MicroRNAs and cancer: short RNAs go a long way. Cell 2009;136:586-591.

13 Parkin DM, Bray F, Ferlay J, Pisani P: Global cancer statistics, 2002. CA Cancer J Clin 2005;55:74-108.

14 Xia X, Yang B, Zhai X, Liu X, Shen K, Wu Z, Cai J: Prognostic role of microRNA-21 in colorectal cancer: a meta-analysis. PLoS One 2013;8:e80426.

15 Zhang J, Lu Y, Yue X, Li H, Luo X, Wang Y, Wang K, Wan J: MiR-124 suppresses growth of human colorectal cancer by inhibiting STAT3. PLoS One 2013;8:e70300.

16 Lou X, Qi X, Zhang Y, Long H, Yang J: Decreased expression of microRNA-625 is associated with tumor metastasis and poor prognosis in patients with colorectal cancer. J Surg Oncol 2013;108:230-235.

17 Zhou C, Liu G, Wang L, Lu Y, Yuan L, Zheng L, Chen F, Peng F, Li X: MiR-339-5p regulates the growth, colony formation and metastasis of colorectal cancer cells by targeting PRL-1. PLoS One 2013;8:e63142.

18 Ye J, Wu X, Wu D, Wu P, Ni C, Zhang Z, Chen Z, Qiu F, Xu J, Huang J: miRNA-27b targets vascular endothelial growth factor $\mathrm{C}$ to inhibit tumor progression and angiogenesis in colorectal cancer. PLoS One 2013;8:e60687.

19 Zhang W, Zou C, Pan L, Xu Y, Qi W, Ma G, Hou Y, Jiang P: MicroRNA-140-5p inhibits the progression of colorectal cancer by targeting VEGFA. Cell Physiol Biochem 2015;37:1123-1133. 


\section{Cellular Physiology Cell Physiol Biochem 2016;39:1165-1176

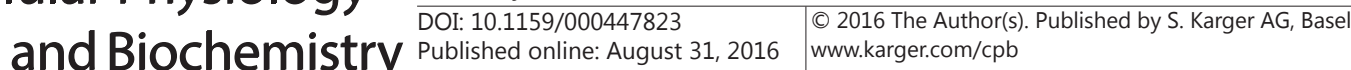 \\ Wei et al.: MiRNA-30a Suppresses CRC Metastasis via ITGB3}

20 Xu K, Liu X, Mao X, Xue L, Wang R, Chen L, Chu X: MicroRNA-149 suppresses colorectal cancer cell migration and invasion by directly targeting forkhead box transcription factor FOXM1. Cell Physiol Biochem 2015;35:499-515.

21 Fang Y, Sun B, Xiang J, Chen Z: MiR-301a promotes colorectal cancer cell growth and invasion by directly targeting SOCS6. Cell Physiol Biochem 2015;35:227-236.

22 Cummins JM, He Y, Leary RJ, Pagliarini R, Diaz LA, Jr., Sjoblom T, Barad O, Bentwich Z, Szafranska AE, Labourier E, Raymond CK, Roberts BS, Juhl H, Kinzler KW, Vogelstein B, Velculescu VE: The colorectal microRNAome. Proc Natl Acad Sci U S A 2006;103:3687-3692.

23 Arndt GM, Dossey L, Cullen LM, Lai A, Druker R, Eisbacher M, Zhang C, Tran N, Fan H, Retzlaff K, Bittner A, Raponi M: Characterization of global microRNA expression reveals oncogenic potential of miR-145 in metastatic colorectal cancer. BMC Cancer 2009;9:374.

24 Sarver AL, French AJ, Borralho PM, Thayanithy V, Oberg AL, Silverstein KA, Morlan BW, Riska SM, Boardman LA, Cunningham JM: Human colon cancer profiles show differential microRNA expression depending on mismatch repair status and are characteristic of undifferentiated proliferative states. Bmc Cancer 2009;9:401-401.

25 Baraniskin A, Birkenkamp-Demtroder K, Maghnouj A, Zollner H, Munding J, Klein-Scory S, Reinacher-Schick A, Schwarte-Waldhoff I, Schmiegel W, Hahn SA: MiR-30a-5p suppresses tumor growth in colon carcinoma by targeting DTL. Carcinogenesis 2012;33:732-739.

26 Zhong M, Bian Z, Wu Z: miR-30a suppresses cell migration and invasion through downregulation of PIK3CD in colorectal carcinoma. Cell Physiol Biochem 2013;31:209-218.

27 Zhang Q, Tang Q, Qin D, Yu L, Huang R, Lv G, Zou Z, Jiang XC, Zou C, Liu W, Luo J, Zhao Z, Muhammad S, Wang G, Chen YG, Wang X: Role of microRNA 30a targeting insulin receptor substrate 2 in colorectal tumorigenesis. Mol Cell Biol 2015;35:988-1000.

28 Zhao Y, Miao G, Li Y, Isaji T, Gu J, Li J, Qi R: MicroRNA- 130b suppresses migration and invasion of colorectal cancer cells through downregulation of integrin beta1 [corrected]. PLoS One 2014; 9:e87938.

29 Braun J, Hoang-Vu C, Dralle H, Huttelmaier S: Downregulation of microRNAs directs the EMT and invasive potential of anaplastic thyroid carcinomas. Oncogene 2010;29:4237-4244.

30 Brabletz T: To differentiate or not--routes towards metastasis. Nature Reviews Cancer 2012;12:425-436.

31 Lee JM, Dedhar S, Kalluri R, Thompson EW: The epithelial-mesenchymal transition: new insights in signaling, development, and disease. J Cell Biol 2006;172:973-981.

32 Peinado H, Olmeda D, Cano A: Snail, Zeb and bHLH factors in tumour progression: an alliance against the epithelial phenotype? Nat Rev Cancer 2007;7:415-428.

33 Zeisberg M, Neilson EG: Biomarkers for epithelial-mesenchymal transitions. J Clin Invest 2009;119:14291437.

34 Wang B, Li W, Liu H, Yang L, Liao Q, Cui S, Wang H, Zhao L: miR-29b suppresses tumor growth and metastasis in colorectal cancer via downregulating Tiam1 expression and inhibiting epithelialmesenchymal transition. Cell Death Dis 2014;5:e1335.

35 Moyer MP, Manzano LA, Merriman RL, Stauffer JS, Tanzer LR: NCM460, a normal human colon mucosal epithelial cell line. In Vitro Cell Dev Biol Anim 1996;32:315-317.

36 Schmittgen TD, Livak KJ: Analyzing real-time PCR data by the comparative C(T) method. Nature Protocols 2008;3:1101-1108.

37 Ilya I, Sashwati R, Sen CK: Algorithms for mapping of mRNA targets for microRNA. Dna \& Cell Biology 2007;26:265-272.

38 Zhao L, Xu J, Liang F, Li A, Zhang Y, Sun J: Effect of Chronic Psychological Stress on Liver Metastasis of Colon Cancer in Mice. PLoS One 2015;10:e0139978.

39 Lu J, Getz G, Miska EA, Alvarez-Saavedra E, Lamb J, Peck D, Sweet-Cordero A, Ebert BL, Mak RH, Ferrando AA, Downing JR, Jacks T, Horvitz HR, Golub TR: MicroRNA expression profiles classify human cancers. Nature 2005;435:834-838.

40 Volinia S, Calin GA, Liu CG, Ambs S, Cimmino A, Petrocca F, Visone R, Iorio M, Roldo C, Ferracin M, Prueitt RL, Yanaihara N, Lanza G, Scarpa A, Vecchione A, Negrini M, Harris CC, Croce CM: A microRNA expression signature of human solid tumors defines cancer gene targets. Proc Natl Acad Sci USA 2006;103:2257-2261.

41 Hood JD, Cheresh DA: Role of integrins in cell invasion and migration. Nat Rev Cancer 2002;2:91-100.

42 Guo W, Giancotti FG: Integrin signalling during tumour progression. Nat Rev Mol Cell Biol 2004;5:816-826. 


\section{Cellular Physiology Cell Physiol Biochem 2016;39:1165-1176

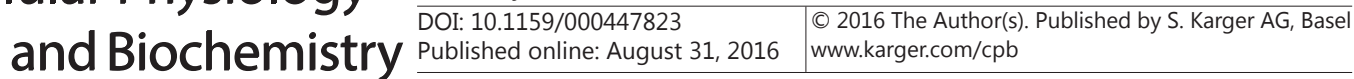 \\ Wei et al.: MiRNA-30a Suppresses CRC Metastasis via ITGB3}

43 Switala-Jelen K, Dabrowska K, Opolski A, Lipinska L, Nowaczyk M, Gorski A:The biological functions of beta3 integrins. Folia Biologica 2004;50:143-152.

44 Guan JL: Role of focal adhesion kinase in integrin signaling. Int J Biochem Cell Biol 1997;29:1085-1096.

45 Yang C, Li LI, Wang C, Chen LH, Feng LI, Yan L, Cheng H: Introduction of p130cas signaling complex formation upon integrin-mediated cell adhesion: a role for Src family kinases. Mol Cell Biol1996;16:26062613.

46 Niels R, Wenbiao L, Ahmad SA, Fan F, Oliver S, Parikh AA, Bucana CD, Gallick GE, Nickols MA, Westlin WF: Alphavbeta3 integrin antagonist S247 decreases colon cancer metastasis and angiogenesis and improves survival in mice. Cancer Research 2003;63:2079-2087.

47 Lei Y, Huang K, Gao C, Lau QC, Pan H, Xie K, Li J, Liu R, Zhang T, Xie N, Nai HS, Wu H, Dong Q Zhao X, Nice EC, Huang C, Wei Y: Proteomics identification of ITGB3 as a key regulator in reactive oxygen speciesinduced migration and invasion of colorectal cancer cells. Mol Cell Proteomics 2011;10:M110 005397.

48 Zha R, Guo W, Zhang Z, Qiu Z, Wang Q, Ding J, Huang S, Chen T, Gu J, Yao M, He X: Genome-wide screening identified that miR-134 acts as a metastasis suppressor by targeting integrin beta1 in hepatocellular carcinoma. PLoS One 2014;9:e87665.

49 Sun L, Liu B, Lin Z, Yao Y, Chen Y, Li Y, Chen J, Yu D, Tang Z, Wang B, Zeng S, Fan S, Wang Y, Li Y, Song E, Li J: MiR-320a acts as a prognostic factor and Inhibits metastasis of salivary adenoid cystic carcinoma by targeting ITGB3. Mol Cancer 2015;14:96. 